\title{
EDUKACINE் VEIKLA KAIP INTEGRALIOS SVEIKATOS PRIEŽIŪROS SĄLYGA: TEORINĖS İŽVALGOS IR PRAKTINIS PRITAIKOMUMAS
}

\author{
Augustas Česnavičius ${ }^{1}$, Samanta Savickaitė ${ }^{2}$, Jurga Remeikiené $\dot{e}^{3}$, Alisa Maksimova ${ }^{1}$, \\ Agnẻ Čižauskaitėe, ${ }^{4,5}$, Alvydas Česas ${ }^{5}$ \\ ${ }^{1}$ Lietuvos sveikatos moksly universiteto Medicinos akademijos Medicinos fakultetas, \\ ${ }^{2}$ Klaipedos universitetas, Socialiniu mokslu fakultetas, \\ ${ }^{3}$ Klaipèdos universitetinès ligoninès Radioterapijos ir branduolinès medicinos centras, \\ ${ }^{4}$ Klaipedos universitetas, Sveikatos mokslu fakulteto Slaugos katedra, \\ ${ }^{5}$ Klaipèdos universitetinès ligoninès Onkologijos chemoterapijos klinika
}

Raktažodžiai: krūties vėžys, pacientų edukacija, informacijos poreikis, psichosocialinè gerovè, integrali sveikatos priežiūra.

\begin{abstract}
Santrauka
Tyrimo tikslas - aptarti teorinius ir praktinius pacientų edukacijos aspektus kaip integralią krūties vèžiu sergančių pacienčių sveikatos priežiūros sąlygą. Mokslinès literatūros studijos atskleidè, kad pacientų, sergančių navikinėmis ligomis, edukacija yra labai aktuali problema visuomeneje. Onkologiniams ligoniams būdingų fizinių, socialinių ir psichologinių problemų kontekste informacijos poreikis apie ligą ir pagalbos galimybes yra vienas iš svarbiausių. Ypatingas dèmesys turètų būti skiriamas krūties vèžiu sergančioms moterims, kadangi tai dažniausiai diagnozuojama jų onkologinè liga, ir moterims kyla didesnè rizika patirti stiprų nerimą ar netgi susirgti depresija ligos gydymo laikotarpiu. Tuo tarpu moksliniu tyrimų rezultatai parodè, kad edukacinè veikla teikia ịvairialypę naudą pirmiausia patiems pacientams bei ji gydantiems specialistams. Edukacinès intervencijos paneigia klaidingus ịsitikinimus, „stigmas“, kuriuos pacientai neretai sužino naršydami internete, paskatina aktyviau dalyvauti savo ligos gydyme, gerina pacientų gyvenimo kokybę ir prisideda prie sklandesnių ligos gydymo procesų užtikrinimo.
\end{abstract}

\section{İvadas}

Pastaraisiais dešimtmečiais vis daugiau dèmesio skiriama pacientų, sergančių navikinėmis ligomis, edukacijai. Pagrindinè diskusijų apie pacientų švietimą priežastis: dauguma pacientų vėžio diagnozès ir ligos gydymo metu neturi pakankamos informacijos apie ligą, jos eigą, gydymo principus. Visų procesų eigoje iškyla daug pacientams svarbių klausimų, todèl jiems reikalinga informacija, padedanti geriau suprasti ligos eigą ir gydymą [1,2].

Vertètų pabrèžti, kad pacientams teikiama informacija turi būti individualizuota, t.y. pritaikyta jų ligos situacijai, todèl informacijos, kuri turètų būti teikiama pacientams, pobūdis reikšmingai priklauso nuo vėžio lokalizacijos ir kitų su liga susijusių aspektų. Atsižvelgiant ị faktą, kad krūties vėžys - dažniausiai diagnozuojama onkologinė moterų liga, antra pagal dažnumą onkologinè liga pasaulyje, o Lietuvoje 2017 metais šią diagnozę išgirdo 12809 moterys [3,4], galima argumentuotai teigti, kad dèmesys krūties vėžiu sergančiu moterų kompleksiniams poreikiams, taip pat ir informacijai, yra ypač aktualus mūsų visuomenejje.

PSO duomenimis, tinkamas supažindinimas su liga yra siejamas su geresne gyvenimo kokybe [5]. Tyrimai rodo, jog edukacinė veikla teikia ịvairialypę naudą pirmiausia patiems pacientams bei ji gydantiems specialistams. Vykdant ịvairias edukacinio pobūdžio intervencijas dažniausiai stiprinamas sveikatos priežiūros specialistų ir pacientų tarpusavio bendradarbiavimas, gerinama paciento psichologinè būklè ir emociné savijauta, o tai akcentuojama kaip vienas iš didžiausių šviečiamojo pobūdžio veiklos privalumų. Be to, pacientu mokymas paneigia klaidingus įsitikinimus, ,,stigmas", kuriuos pacientai neretai igyja naršydami internete ir dèl kurių neretai bijo pradèti gydymą ar netgi jo atsisako. Pacientų švietimas paskatina pačius pacientus aktyviau dalyvauti gydymo procese, laikytis gydymo rekomendacijų bei pagerina gyvenimo kokybę ir patirtis [1,2].

Straipsnio tikslas: aptarti teorinius ir praktinius pacientų edukacijos aspektus kaip integralią krūties vėžiu sergančių pacienčių sveikatos priežiūros sąlygą. 


\section{Tyrimo medžiaga ir metodika}

Šio straipsnio tyrimo objektas: edukacinè veikla kaip integralios sveikatos priežiūros sąlyga. Straipsnyje atsižvelgiant ị mokslinèje literatūroje aptartus pagrindinius krūties vėžiu sergančių pacienčių informacijos poreikius aptariama edukacinių intervencijų nauda onkologiniams pacientams, pristatoma „Pacientų, sergančių krūties vèžiu, mokyklos““ iniciatyva Klaipėdos universitetinèje ligoninejje. Išanalizuota mokslinè literatūra pacientu edukacijos klausimais pagal pacientų informacijos poreikių ir edukacinių intervencijų naudingumo kriterijus. Darbe taip pat taikytas aprašomasis metodas, siekiant pristatyti pacientų mokyklos iniciatyvą Klaipèdos universitetinèje ligoninèje.

Edukacinių intervencijų poreikis ir nauda onkologijos pacientams. Mokslinių tyrimų rezultatai leidžia teigti, kad dauguma onkologinès ligos diagnozę išgirdusių asmenų susiduria su kompleksinemis problemomis: ne tik fizinèmis, bet ir dvasinèmis, psichologinèmis bei socialinèmis. Minètų problemų kontekste viena iš svarbiausių yra informacijos poreikis apie ligą ir pagalbos galimybes [6,7]. Vertètų pabréžti, kad moterims kyla didesnè rizika patirti stiprų nerimą ar netgi susirgti depresija onkologinès ligos gydymo laikotarpiu, todèl dèmesingumas šios tikslinès grupès informacijos poreikiams turi būti adekvatus $[1,10]$.

Kadangi pacientès, sužinojusios diagnozę, patiria didžiuli stresą, natūralu, jog ieško daugiau informacijos apie ligą bei gydymą. Tyrimai rodo, kad apie $85 \%$ pacienčių papildomai domisi pačia liga [1]. Daugiau nei pusè moterų nori žinoti ligos gydymo galimybes bei galimas komplikacijas, vienas populiariausių klausimų - mitybos pokyčiai gydymo metu $[1,10]$. Mažiausiai domimasi ligos progresavimo greičiu [1], ligos etiologija ir prevencija [11].

Pacientès, sergančios krūties vèžiu, dažnai būna išsigandusios ir pažeidžiamos. Todèl tinkamas reikiamos informacijos suteikimas gali sumažinti streso lygi, pagerinti gyvenimo kokybę bei pasitikejimą savimi. Internetas - labai patogus ir greitas informacijos šaltinis. Kaip rodo tyrimai, net $40 \%$ pacientų naudoja internetą, kad atsakytų i iškilusius klausimus. Tačiau naršymas internete gali būti žalingas dèl didelio kiekio nepatikimos informacijos, kuri pacientams gali sukelti nerimą bei sumaištį. Nors tai yra moderni priemoné efektyviai surasti reikiamą informaciją, vis dèlto pats populiariausias informacinis šaltinis - gydantis gydytojas $[12,13]$. Tačiau ir čia yra sunkumų. Dėl gydytojų, slaugytojų laiko bei komunikacijos stokos sudètinga pateikti visą informaciją suprantamai. Todèl beveik pusè moterų lieka nepatenkintos gydytojų ir slaugytojų suteiktomis žiniomis [13]. Mažiausiai naudojami informacijos šaltiniai - brošiūros bei medicininiai žurnalai [14]. Jaunesnès nei 45 metų moterys nèra patenkintos informacijos kokybe ir kiekybe, kurią joms suteikia gydytojai $[11,12]$. Pastebèta, kad moterų, kurių liga diagnozuota prieš 3 mènesius, informacijos poreikis yra didesnis. Tačiau šis rodiklis sumažèja po 6 mènesių, nes pacientès jau yra gydomos ir būna susidūrusios su pašaliniais poveikiais [12]. Taigi medicinos darbuotojai kartais dar nepakankamai ìvertina pacientų žinių poreikį. Tikintis geresnès gydymo kokybès ir paciento pasitenkinimo paslaugomis - svarbu padèti sergančiajam kuo geriau suprasti savo ligą ir lavinti ligos valdymo ịgūdžius.

Onkologinių pacientų švietimo nauda gali būti vertinama tiek iš paciento, tiek iš specialisto perspektyvų bei įvairiais aspektais: daroma itaka specialisto ir paciento bendradarbiavimui, gydymo sklandumui, paciento gyvenimo kokybei ir kt. Mokslinių tyrimų rezultatai rodo, kad vertinant pacientų švietimo naudą iš paciento perspektyvos, galima teigti, kad švietimas gydymo, jo šalutinių poveikių ir laukiančių procedūrų klausimais sumažina pacientų patiriamą nerimą bei baimę, depresijos išsivystymo tikimybę $[15,16]$, taip pat padidina žinojimą ir užtikrina pozityvias patirtis gydymo eigoje [17].

Tyrimuose išskiriami pirminiai ir antriniai pacientų šviečiamojo pobūdžio intervencijų rezultatai. Pirmiausia atskleista nauda pacientu gyvenimo kokybei bendraja prasme, o kaip antrinè edukacinių veiklų išdava išskiriami geresni psichosocialiniai ịgūdžiai, susiję su patiriamo emocinio distreso, ligos simptomų valdymu, didesne saviverte ir pasitikejjimu, padidejusiomis žiniomis apie ligą. Šviečiamojo pobūdžio intervencijos taip pat susijusios ir su fizinių ligos simptomų palengvinimu [18,19]. Edukacinès programos, pagal kurias vykdomos tokios veiklos kaip fizinio aktyvumo užsièmimai, relaksacijos mokymai, mitybos ịpročių ugdymas, daro reikšmingai teigiamą poveikį lètinio nuovargio, atsiradusio dèl onkologinès ligos, mažinimui [19].

Mokslinejje literatūroje taip pat išskiriama edukacinès veiklos nauda su ligoniu dirbantiems specialistams, organizacijai ir sveikatos priežiūrai plačiaja prasme. Pastebėtina, kad pacientų švietimas yra labai svarbus elementas siekiant užtikrinti kokybišką onkologinių ligonių sveikatos priežiūrą [23]. Tikslinga šviečiamojo pobūdžio veikla gali sutrumpinti gulëjimo ligoninejje trukmę, pakartotinų apsilankymų pas specialistą skaičių bei sumažinti gydymo kaštus [16, 20-22]. Taip pat pacientų švietimas gali būti laikomas įrankiu, užtikrinančiu sklandesni ligos gydymo procesą, nes pacientai, turintys jiems reikalingos ir patikimos informacijos, dažniau laikosi gydymo rekomendacijų. Kompetentingos informacijos turejimas igalina pacientus aktyviau dalyvauti savo ligos gydyme, pagerina komunikaciją ir bendradarbiavimą su specialistais $[18,24]$.

Pacientų, sergančių krūties vèžiu, mokyklos Klaipèdos universitetinėje ligoninėje veiklos apžvalga. Šiuolai- 
kinèje sveikatos priežiūroje terminai paciento „gyvenimo kokybe“" ir „pasitenkinimas paslaugomis“ tampa ne mažiau svarbūs nei gydymas moderniausiomis technologijomis ir metodais. Todèl $i$ asmenį orientuotas kompleksinis gydymas palaipsniui integruojamas ị rutininę gydymo įstaigų veiklą ir vis daugiau gydytojų i pacientą pradeda žiūretti holistiškai. Pabrežtina, kad informacijos ir pagalbos paslaugos laikomos vienu optimaliausių irankių šiems siekiams iggyvendinti. Atsižvelgiant ị pastarąsias tendencijas, ịtvirtintas mokslinių tyrimų rezultatuose bei tarptautinio lygmens dokumentuose bei remiantis darbo su pacientais praktika, Klaipedos universitetinèje ligoninėje susibūrè onkologijos srityje dirbančių specialistų iniciatyvinè grupè. Ši grupè parengè projektą steigti „Pacientų, sergančių krūties véžiu, mokyklą“. Projektas bus praktiškai iggyvendinamas jau nuo 2019 m. pradžios.

Pacientų mokyklos veikla pirmiausia bus orientuota i krūties piktybinèmis ligomis sergančius asmenis ir jų artimuosius. Planuojama dirbti ir su kitomis onkologinemis ligomis sergančiais pacientais. Pagrindinis mokyklos tikslas - šiuo metu pagerinti krūties véžiu sergančių pacientų sveikatos priežiūros rezultatus ir palengvinti jiems keliamą ligos „naštą" formuojant ligos valdymo, sveikatos savikontrolès igūdžius. Šiems siekiams ịgyvendinti bus vykdomos įvairios edukacinès intervencijos, pradedant nuo informacijos dalijimosi ir bendravimo su pacientais paskaitu metu ir baigiant praktiniais užsiemimais.

Pacientų mokykloje aptariamų temų spektras labai platus: nuo konkrečių su tyrimais, gydymu ir jo šalutiniais reiškiniais susijusių klausimų iki praktinių mitybos, fizinio aktyvumo, tarpasmeninių santykių, ivvairių baimių ir streso įveikos bei dvasinio pobūdžio rekomendacijų. Iš viso numatytos 6 didelès temų grupès (nuo diagnozès konstatavimo iki gyvenimo po gydymo). Taigi užsièmimų metu įstaigoje dirbantys sveikatos priežiūros specialistai suteiks informaciją, kuri sergančiajam svarbi, kai reikia priimti su gydymu susijusius sprendimus, ivveikti su liga susijusius fizinius ir psichosocialinius iššūkius, integruotis ị kasdienį gyvenimą po aktyvaus gydymo laikotarpio.

Kad savanoriškais pagrindais mokykloje dirbančių specialistų teikiama informacija ir pagalba būtų visiems suprantama ir prieinama, numatyta pasitelkti moderniausias komunikacines priemones, vizualinę medžiagą ir kt. Pacientai taip pat turès nuotolinę prieigą prie patogiai valdomos informacijos apie onkologines ligas, kuri bus patikima ir pagrịsta klinikinėmis praktinèmis rekomendacijomis.

Minèta specialistų iniciatyva siekiama praplèsti pacientu žinojimą apie savo ligą ir jos gydymą, padidinti pasitikejjimą gydančiu personalu ir pasitenkinimą paslaugomis, ugdyti ligos valdymo igūdžius, užtikrinti patikimos informacijos prieinamumą. Manoma, kad dèl šioje mokykloje vykdomų veiklų bus sumažintas pacientų patiriamas stresas ir distresas, bejègiškumo jausmas, nepasitikèjimas sveikatos priežiūros sistema ir pasimetimas gydymo procese, o tai nulems ir mažesnị papildomų (neefektyvių) sveikatos priežiūros paslaugų naudojimą ir didins pasitenkinimą teikiamų paslaugų kokybe.

\section{Išvados}

1. Krūties vėžys - dažniausiai diagnozuojama onkologinè liga tarp moterų bei antra pagal dažnumą onkologinė liga pasaulyje. Informacijos poreikis krūties vèžiu sergantiesiems yra labai aktuali ir svarbi tema. Onkologine liga sergančiujų informacijos klausimai yra ịvairialypiai. Pacientams reikalinga informacija apie jų ligą, gydymo ypatumus bei papildomos pagalbos galimybes.

2. Tikslingas informacijos suteikimas, edukacinių intervencijų vykdymas rutininejje gydymo įstaigų praktikoje reikšmingai susijęs su gydymo procesų sklandumo užtikrinimu, teikiamų paslaugų kokybe ir pacientų pasitenkinimu. Kompleksinių pacientų informacijos poreikių tenkinimas vykdant įvairias edukacinio pobūdžio veiklas laikytinas integralios, aukščiausios kokybès sveikatos priežiūros sąlyga.

3. Atsižvelgiant ị pasaulinę praktiką, mokslinių tyrimų tendencijas ir darbinę gydytojų patirtí, Klaipedos universitetinèje ligoninèje nuo 2019 m. pradžios pradès veikti „Pacientų, sergančių krūties véžiu, mokykla“, kurios tikslas spręsti šiame straipsnyje aptartas pacientų edukacijos problemas.

\section{Literatūra}

1. Kimiafar K, Sarbaz M, Shahid Sales S, Esmaeili M, Javame Ghazvini Z. Breast cancer patients' information needs and information-seeking behavior in a developing country. The Breast 2016;28:156-160.

https://doi.org/10.1016/j.breast.2016.05.011

2. Berger O, Grønberg B, Loge J, Kaasa S, Sand K. Cancer patients' knowledge about their disease and treatment before, during and after treatment: a prospective, longitudinal study. BMC Cancer 2018;18(1). doi:10.1186/s12885-018-4164-5 https://doi.org/10.1186/s12885-018-4164-5

3. Bray F, Ferlay J, Soerjomataram I, Siegel R, Torre L. and Jemal A. Global cancer statistics 2018: GLOBOCAN estimates of incidence and mortality worldwide for 36 cancers in 185 countries. CA: A Cancer Journal for Clinicians, 2018. https://doi.org/10.3322/caac.21492

4. Higienos institutas. Stat.hi.lt. https://stat.hi.lt/default. aspx?report_id=168. Published 2018. Accessed October 31, 2018.

5. Engqvist Boman L, Sandelin K, Wengström Y, Silén C. Patients ‘ learning and understanding during their breast cancer trajectory. Patient Educ Couns 2017; 100(5):795-804.

https://doi.org/10.1016/j.pec.2016.12.024 
6. Mekuria AB, Erku DA, Belachew SA. Preferred information sources and needs of cancer patients on disease symptoms and management: a cross-sectional study. Patient Prefer Adherence 2016;10:1991-1997. Published 2016 Sep 29.

7. Clarke M, Moore J, Steege L. et al. Health information needs, sources, and barriers of primary care patients to achieve patient-centered care: A literature review. Health Informatics J 2016;22(4):992-1016. https://doi.org/10.1177/1460458215602939

8. Hajian S, Mehrabi E, Simbar M, Houshyari M. Coping strategies and experiences in women with a primary breast cancer diagnosis. Asian Pac J Cancer Prev 2017;18(1):215-224. Published.

9. Lavdaniti M, Barbas G, Fratzana A. et al. Evaluation of depression in colon cancer patients. Hsl 2012; 6:681-92.

10. Maloney EK, D‘Agostino TA, Heerdt A. et al. Sources and types of online information that breast cancer patients read and discuss with their doctors. Palliat Support Care 2013;13(2):10714 .

https://doi.org/10.1017/S1478951513000862

11. Goss C, Deledda G, Bottacini A. et al. Information needs of female Italian breast cancer patients during their first oncological consultation. European Journal of Oncology Nursing 2015;19(5):451-457.

https://doi.org/10.1016/j.ejon.2015.02.003

12. Abi Nader E, Kourie H, Ghosn M et al. Informational needs of women with breast cancer treated with chemotherapy. Asian Pacific Journal of Cancer Prevention 2016;17(4):1797-1800. https://doi.org/10.7314/APJCP.2016.17.4.1797

13. Schmidt A, Ernstmann N, Wesselmann S, Pfaff H, Wirtz M, Kowalski C. After initial treatment for primary breast cancer: information needs, health literacy, and the role of health care workers. Supportive Care in Cancer 2015;

14. Littlechild S, Barr L. Using the Internet for information about breast cancer: a questionnaire-based study. Patient Educ Couns 2013; 92(3):413-417.

https://doi.org/10.1016/j.pec.2013.06.018

15. Garcia $\mathrm{S}$. The effects of education on anxiety levels in patients receiving chemotherapy for the first time: an integrative review. Clin J Oncol Nurs 2014; 18(5):516-521. https://doi.org/10.1188/14.CJON.18-05AP

16. Gordon L, Beesley V, Scuffham P. Evidence on the economic value of psychosocial interventions to alleviate anxiety and depression among cancer survivors: a systematic review. Asia Pac J Clin Oncol 2011;7(2):96-105. https://doi.org/10.1111/j.1743-7563.2011.01395.x

17. Jimenez Y, Cumming S, Wang W, Stuart K, Thwaites D, Lewis S. Patient education using virtual reality increases knowledge and positive experience for breast cancer patients undergoing radiation therapy. Supportive Care in Cancer 2018;26(8):28792888.

https://doi.org/10.1007/s00520-018-4114-4
18. Ellegaard M, Jensen A, Lomborg K. Development of a cancer self-management education programme for women with breast cancer at the end of primary treatment. Journal of Cancer Education 2018.

https://doi.org/10.1007/s13187-018-1390-0

19. Shizheng D, Lingli H, Jianshu D. et al. Patient education programs for cancer-related fatigue: a systematic review. Patient Education and Counseling, November 2015; 98(11):1308-1319. https://doi.org/10.1016/j.pec.2015.05.003

20. Jansen F, van Zwieten V, Coupé VM, Leemans CR, Verdonckde Leeuw IM. A review on cost-effectiveness and cost-utility of psychosocial care in cancer patients. Asia Pac J Oncol Nurs 2016;3(2):125-136.

21. Domain team et al. NHS England: Personalised Care \& Support Planning Handbook 2015. Available at: https://www.england. nhs.uk;

22. Arving C, Brandberg Y, Feldman I, Johansson B, Glimelius B. Cost-utility analysis of individual psychosocial support interventions for breast cancer patients in a randomized controlled study. Psychooncology 2013; 23(3):251-258.

https://doi.org/10.1002/pon.3411

23. Schapira L. 2018. Patient education is an essential element of quality cancer care. ASCO daily news 2018.

24. Gauthier-Frohlick D, Boyko S, Conlon M. et al. Evaluation of cancer patient education and services. Journal of Cancer Education 2010; 25(1):43-48.

https://doi.org/10.1007/s13187-009-0008-y

\section{EDUCATIONAL ACTIVITY AS A CONDITION OF INTEGRAL HEALTH CARE: THEORETICAL INSIGHTS AND PRACTICAL APPLICATION A.Česnavičius, S.Savickaitė, J.Remeikienė, A.Maksimova, A.Čižauskaitė, A.Česas}

Key words: breast cancer, patient education, informational needs, psychosocial well-being, integral health care.

Summary

Education of patients with diagnosed cancer is a major issue in our modern society. Multiple studies show that patients experience multiple social, physical and psychological problems, therefore, the demand of information is high. Special attention should be paid to women diagnosed with breast cancer, as it is the most common cancer disease among them. Consequently, the risk of developing anxiety and depression during treatment is high. Firstly, education is beneficial for both: patients and their doctors. Educational interventions help deny false information and "stigma" which patients learn from the Internet. Furthermore, it encourages people to actively participate in their own treatment planning and helps to increase the quality of life.

Aim of this study: to discuss theoretical and practical aspects of patient education as an integral part of the health care provision for patients with breast cancer.

Correspondence to: samantasavickaite@yahoo.com 